\title{
ANALYSIS PROVISION OF DIRECT INCOME COMPENSATION AND INDIRECT INCOME COMPENSATION ON THE PERFORMANCE EMPLOYEES COMPANY INSURANCE
}

\author{
by \\ Said Khaerul Wasif \\ Sekolah Tinggi Ilmu Ekonomi Indonesia Jakarta, Indonesia \\ Email: saidkhaerulwasif@gmail.com
}

\begin{abstract}
Article Info
Article history:

Received Jun 9, 2018

Revised Nov 20, 2018

Accepted Dec 11, 2018

ABSTRACT (10 PT)

This study aims to analyze the effect of direct financial compensation and indirect financial compensation on the performance of insurance company employeeS.The sample used is 73 employees. The research technique amalysis use is $t$ is multiple linear regression analysi. The results of this study indicate that partially direct income compensation has an effect on employee performance with a value of sig. 0.000 while the indirect income

Keywords:

First keyword

Second keyword

Third keyword

Fourth keyword

Fifth keyword compensation has the same direct effect on employee performance with sig. 0.015. Meanwhile, direct income compensation and indirect income compensation on the performance of insurance company employees have an effect of $74 \%$. The limitations of this study only discuss 3 variables, namely direct income compensation and indirect income compensation and employee performance. It is hoped that this research can be useful for insurance companies and become a reference for further research regarding the analysis of the provision of direct income compensation and indirect income compensation on the performance of employees company insurance.

Keywords: Direct income compensation, indirect income compensation, performance employee performance, insurance
\end{abstract}

This is an open access article under the CC BY-SA license.

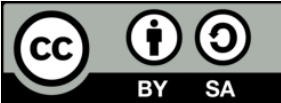

\section{Corresponding Author:}

Said Khaerul Wasif

Sekolah Tinggi Ilmu Ekonomi Indonesia Jakarta, Indonesia

Email: saidkhaerulwasif@ gmail.com

\section{INTRODUCTION (10 PT)}

National and international scale business companies to develop their business always rely on strategies in marketing their products to introduce products and achieve profits. HR plays a very important role in the progress of the company. Competent human resources, full of soft skills, have a strategic role compared to human resources without expertise. A healthy company makes human resources a business partner, not just an asset (Dessler, 2012).

Treating employees fairly by giving awards as a form of gratitude for giving the time, energy, thoughts that have been given to the company. Employees can be more accomplished to advance the company and vice versa employee achievements are rewarded with appropriate compensation as a form of appreciation for their efforts and hard work in participating in developing the company's business business (Rachmawati, 2007). With a mutually supportive and beneficial working relationship between the company and employees, it can improve work performance.

Compensation is a reward or gift given to employees for their achievements and contributions during work (Mangkunegara, 2010). Compensation is given to make employees feel fair and appreciate the efforts that have been 
made in developing a company. The result to be achieved in providing compensation is that employees are interested in providing all ideas and are motivated to work optimally (Damayanti and Sumaryati, 2013).

Compensation always attracts employees to work hard. There are two problems that often arise in companies regarding compensation, namely employees want a large income, while companies are looking for ways so that employee income can be given as efficiently as possible to increase employee motivation (Marihot, 2010). Insurance companies are trying to improve the payroll system that is linked to improving the performance of individuals and work units with the aim of increasing work motivation.

The compensation provided by the company is very valuable for workers/employees, the amount of compensation can be an indicator of the work performance. Compensation will be able to motivate employees and improve work performance. The larger the company provides compensation to its employees, the employee's efforts will increase and even compete to show their work performance, and vice versa if the company's compensation is below the average or lower given by the company, the employee will feel disappointed because of the direct or indirect income compensation. directly given by the company is not in accordance with the effort and hard work that the company gets (Rivai, 2008). The impact will be very bad for the company, can result in the loss of highly competent employees.

In general, the performance of insurance employees is often unstable with the provision of compensation that is not appropriate or likes to change. It is necessary to improve the structure in the provision of compensation, it is feared that it can lead to demotivation for insurance employees who have high performance due to the provision of compensation. The importance of compensation as an indicator of job satisfaction is difficult to predict. Employees think that the rewards they get directly are subjective and become a characteristic of the company. Employee job dissatisfaction in the company is suspected of being unfair in the provision of compensation, the impact of which will decrease morale and work productivity and will cause disputes between employees. The purpose of a company managing compensation is to create fair and proper compensation for workers.

\section{Theoretical Foundation}

Fair compensation is expected by all employees who work in the company, the company's compensation must be appropriate to be able to compete with other companies. In companies, the compensation system can change employee productivity, initiative and innovation. A good reward system for the company needs to be supported also by a rational method that can make employees compensated / paid according to the work demands they do.

Compensation is an income in the form of money or goods, either directly or indirectly, which is obtained by employees in the form of remuneration for contributing to the company. The establishment of a good and effective reward system is an important part of HR management because it can help retain and attract high achieving and talented employees (Hasibuan, 2012). Compensation is a gift or reward obtained as long as employees contribute, innovate, and are loyal in advancing the company. In companies, to maintain HR programs in compensation are no less important (Handoko, 2017).

Compensation is a reward offered by the company in the form of a number of packages as a reward for the dedication and dedication of employees while working (Simamora and Henry, 2016). Compensation is an award given by the company to employees who have contributed to realizing the company's ideals by doing many innovative work creativity programs. Rewards are payments in the form of incentives as a motivation for workers to increase their productivity and work performance (Wilson, 2012)

Compensation is an award or direct reward or indirect reward, both financial and non-financial that the company provides to employees fairly and fairly, as well as in return for their contributions and achievements (Gitosudarmo and Indriyo, 2016)

Compensation is a form of reward to be given to employees who contribute to all forms of energy spent, thoughts in developing the company to achieve maximum profit. A form of motivation for employees in achieving company goals (Ananda, 2015)

Compensation is a sign of retribution for the services that have been provided by employees for their dedication to work. Rewards are a way to develop employee performance satisfaction to improve work performance and motivate workers (Didin, 2011) 
International Journal of Social Science (IJSS)

Vol.1 Issue.3 October 2021, pp: 241-252

ISSN: 2798-3463 (Printed) | 2798-4079 (Online)

DOI: https://doi.org/10.53625/ijss.v1i3.417

There are two forms of compensation

a. Direct Income Compensation

Direct compensation is an award that is given directly to employees who have given dedication and contribution while working for the progress of the company. Direct compensation includes the honorarium generated for the hard work of employees in the form of wages, salaries, incentives, gifts (Dessler, 2012). There are three forms of direct compensation according to Recha (2016), namely:

1. Salary

Salary is a service reward in the form of material provided to employees based on their position and responsibilities during work issued by the company

2. Wages

Wages are a form of direct financial gift that the company gives to its employees by looking at the hours worked, the results of the work completed, the amount of service output they have produced.

3. Bonus

Bonus is a form of direct income given by the company to its employees on the basis of the amount of performance that exceeds the key performance indicators set by the company. bonus is also a result outside of fixed compensation, another term is called a pay for performance plan

Giving incentives, a way to satisfy employees, is intended as a way for companies to motivate their employees for their successful work achievements by providing income beyond the income received (Handoko, 2017). The main purpose is to encourage employees to be more responsible in carrying out their work to increase their work productivity and improve/develop their work skills. The creation of an incentive system is based on the outputs produced by employees in the form of commissions, production bonuses, work experience, scarcity of professions, achievements, and leadership achievements in order to increase company profits. Incentive programs and incentive systems must be appropriate and must be known and understood by all employees. Therefore, it is informed that there is notification of incentive programs to all employees, so that the intensive program can be run smoothly and sustainably, but the size of the incentive must also be adjusted by the company's ability and development, relevant and complete data is needed to support the sustainability of the program and the intensive system.

Incentives are things that can attract the desire of workers to work diligently. Incentives are a good way if applied in the company as an encouragement to prevent the decline in employee productivity and employees can work optimally, so that company income will increase (Mulyadi, 2013). The provision of incentives can be in the form of giving either positive incentives or negative incentives. The provision of incentives that are meant positively or well, namely the company does it by encouraging praise, rewards, issuing positive synergies can be in the form of non-material (Andico and Hadi, 2013). Giving with negative synergy is if one of the employees acts not as expected by the company and if the employee does not perform well, then they will be given warnings, sanctions, penalties, training for employees whose performance is still below the company average.

Several kinds of incentives according to Ekshu and Setiawan (2014) include:

1. Rewards are in the form of material gifts such as money, vouchers, or goods

2. Giving an award such as a promotion

3. The conditions needed to work, such as a comfortable, clean and conducive work atmosphere

4. Have satisfaction with work results

5. Satisfaction in establishing cooperative relationships both socially and individually

6. Quickly adjust to company rules, behavior of coworkers, unstable workload

7. A sense of always wanting to follow in every important company event or an event that rarely happens

So it can be concluded that the form of incentives provided can be in the form of material income or nonmaterial income. Material incentives are gifts from the company given to employees in the form of income in the form of money or goods, in the form of commissions, in the form of bonuses and profit sharing. Economic income can increase employee loyalty and welfare. Non-material rewards are gifts given by the company to its workers/employees in the form of awards, both verbal and written compliments, award certificates, promotions and so on.

b Indirect income compensation

Giving gifts to employees as an additional form based on leadership policies with the aim of improving employee welfare outside of fixed income can be in the form of financial, goods. Indirect compensation will not be directly related to the daily work done by employees. One that includes indirect income compensation can be in the form of social assistance (bansos), education, life and health insurance (Ananda, 2016). Indirect financial payments given to employees as a form of sign so that they can continue their next job in the company. 
Indirect income compensation includes the satisfaction obtained by each employee for the work he does as well as in terms of environmental and psychological factors where the employee is placed to work. The type of nonfinancial compensation consists of the satisfaction obtained from doing the work given daily. Non-financial forms of compensation involve the physical and psychological environment in which the person works. Forms of compensation include:

- Employment: career advancement opportunities, interesting assignments, opportunities for recognition of achievements, challenges and responsibilities.

- In terms of the work environment: co-operative co-workers, a symbol of the desired work status, comfortable working environment conditions, flexible time, compressed working time, fair division of labor, canteen compensation,

The form of indirect benefits is divided into 3 namely Simamora and Henry (2016):

1. Benefits in the form of income such as benefits for social security, pensions, and programs for underprivileged and disabled employees that are short or long term to replace lost income due to illness or disability.

2. Benefits programs that open opportunities for employees, which can cover tuition payments to holidays and holidays.

3. Facilities are benefits obtained by executives related to their position/position and status in the company. According to Dessler (2012), there are various forms of benefits for employees including:

1. Employee safety benefits.

Such as accident insurance, health, death, pension funds, home loan benefits and so on is one of the safety benefits.

2. Benefits don't work

Including money for vacation, maternity leave, maternity leave, state duties and others, is one of the benefits when not working.

3. Bonus

Eid gifts, Christmas and New Year's, birthday gifts, company profit bonuses and others, are one form of bonuses.

4. Service program

Such as providing scholarships, providing special loans, subscribing to magazines, providing joint recreation, etc., are a form of service program for employees of the company.

Compensation has a purpose and function. The functions of compensation according to Marihot (2012) are:

1. Efficient Allocation of Human Resources.

Companies that provide good rewards to all employees who have high loyalty, can improve the performance or productivity of these employees so that they can work more optimally.

This can make employees from other companies with lower compensation to be attracted to move to companies that are much better compensated by competing, increasing work ethic and better performance than other employees.

2. More Efficient and Effective Use of Human Resources.

Giving large compensation from the company to its better employees, will be able to make these employees motivated so that they can work more effectively and more efficiently so that their work productivity increases. And with good work productivity will affect the profits obtained by the company

3. Encouraging Economic Stability and Growth.

The impact of the allocation of utilizing human resources in a company can be carried out effectively and efficiently as possible. The direct compensation system is widely expected to increase the stability of the company as well as to help increase the overall economic growth. Good economic stability means the company's finances are more stable, if the company's finances are stable, the company can create a good reward system. The rewards can be direct or indirect.

Purpose and Principles of Compensation

Opinions of experts regarding the purpose of providing compensation vary, but the principle is the same. The objectives of compensation according to Hasibuan (2012) are as follows:

1. Cooperation Bond 
International Journal of Social Science (IJSS)
Vol.1 Issue.3 October 2021, pp: 241-252
ISSN: 2798-3463 (Printed) | 2798-4079 (Online)

DOI: https://doi.org/10.53625/ijss.v1i3.417

A cooperative bond that goes well between the company and its employees, if the employees carry out the tasks or jobs that have been given by the company as well as possible, and the company reciprocates by being obliged to provide fair compensation and in accordance with what has been mutually agreed upon in the agreement.

2. Job Satisfaction

Providing compensation in accordance with the work of employees in remuneration for the company. Where employees feel that all their needs are fulfilled, both from social status, individual interests, job satisfaction from the position carried out

3. Effective Procurement

If the defined benefit plan is large enough, the procurement of qualified employees will be easier

4. Motivation

If the manager in the company gets a large enough compensation, it will be easier for him to motivate his subordinates

5. Employee Stability

The higher the compensation given, the higher the stability of the employees

6. Discipline

If the remuneration given is large, it will increase the discipline of the employee so that they can train their personality in order to create good performance

7. Trade Union Influence

If the compensation program in the company is implemented properly and the compensation is fair, then the influence of labor unions can be avoided.

8. Government Influence

If the compensation program in the company is in accordance with applicable labor laws (such as minimum wage limits) then government intervention can be avoided by the company.

A company must determine compensation in accordance with the principle of compensation.

The principle of compensation in a good company must be based on fair and proper principles and maintain the applicable labor law, according to Hasibuan (2012).

1. Fair Principle

Compensation must be measured based on the magnitude of the job responsibilities, the type of work, the employee's work performance, and the position

2. Decent and reasonable principle

The compensation determined by a company must be adjusted to its eligibility. Even though the level of feasibility measurement is still very relative, the company can also adjust it to a reasonable limit in accordance with the provisions of the government regulations set

Many factors - factors that can affect the compensation system provided to employees of the company.

The following factors are a challenge for companies in determining compensation fairness for employees so that there are no disputes between employees when receiving compensation, including (Hasibuan, 2012):

1. Supply and Demand.

If there are few job vacancies (demand) from interested job seekers (offers), the less compensation received. Likewise, more job vacancies (demand) compared to job seekers (offers) make the compensation received more and more.

Companies that lack and really need manpower, to be able to find qualified personnel, of course, must dare to give big rewards. The more supply of labor outside, the more meaning the job seeker is high enough for a job, of course the company tends to provide a small income.

2. Willingness and Ability of the Company.

The company's ability to repay services is lacking, so the level of compensation received by employees is relatively small. If the company's ability and willingness to repay services is getting better, then the level of compensation that the company will provide is relatively larger. The amount of compensation that will be given by the company to its employees depends on the financial capability of the company, as well as how much the company's ability or willingness to determine the amount of compensation given to its employees.

3. Trade Unions/Employees' Organizations.

The labor union in a company can also determine the level of compensation that will be obtained in the company, because if the labor union in the company is not strong/weak and has no effect, then the compensation given is 
relatively small. If the labor union in the company is strong and influential, the higher the level of compensation given

4. Government with laws and Presidential Decrees.

The size of the minimum wage/remuneration limit is based on the government by law and Presidential Decree. This regulation aims so that employers do not arbitrarily determine the amount of remuneration for employees, therefore this government regulation is important because it is a form of way to stay away from workers from arbitrary actions by the company. The government is obliged to protect the public from arbitrary actions.

\section{Cost of Living / Living Cost.}

The cost of living in an area varies, if the cost of living in the area is low, the standard of compensation that will be set by a company in the area is relatively small. But if the cost of living in the area is high, the standard of compensation that will be set by the company in that area will be large. In other words, the low or high cost of living in an area will determine the amount of compensation that will be set by the company in that area.

6. Employee Position.

If the position received by an employee is low, the level of salary that will be obtained is relatively small. And if the position received by an employee is high, then the level of salary he will get is even greater, because a high position has a great responsibility. In other words, the position of an employee will affect the level of compensation that will be obtained by the employee.

7. Education and Work Experience.

Employees who have a high educational background and have work experience in a company for a long time, then the level of salary given will be large. And if employees who have low education and have little work experience, the level of salary given will be relatively small. In other words, good educational background and work experience play an important role for the company to determine the amount of compensation that will be given to the employee.

According to Moheriono (2014) the application of the compensation payment system in general can be applied including:

1. Time system

Time system compensation is determined on the basis of time provisions such as days, months, hours, weeks, or holidays. In this time system, if work performance is difficult to determine per unit, for permanent employees the income will be paid according to the time system every month. The good thing about this time system is that the administration of wages is easy and the amount of compensation to be given is constant. And the drawback of this time system for the company is that employees who are not diligent will still be compensated for the amount of the agreed agreement.

2. Result system

The amount of income imposed by the company on the units obtained by employees, such as per meter, per piece, per liter, and per kilogram. In the result system, the amount of compensation that will be given to employees is always based on the amount of work done and not based on the duration of the work. The good thing about this result system is that it frees all employees to work optimally and seriously to have good performance with the orientation of getting rewards, greater compensation. The result system also has weaknesses in terms of the quality of the output produced is not optimal, employees who cannot and are not able to produce good work then this results system will work less well because it will provide a small fee for services

3. Wholesale system

Determination of employee payments based on the duration of the work, the size of the weight of the work, the duration of the work is called the piece system. In determining the size of the rewards given by employees, it is based on the calculation of the length of work and the level of difficulty of the work.

Problems in providing wages and salaries are often encountered in implementation, such as those relating to the systematic payment process, determining employee payments, providing incentives, payment flows, how to control payments, minimizing payments to be efficient.

The amount of payment needs to be determined both in terms of the size of the job salary level. Considerations that can be made by looking at how difficult the work is, how much responsibility the job will have for a position.

Aspects of job demands that need to be assessed are as follows:

a. The demand for skill skills consisting of large experience, level of independence, knowledge insight

b. Demands for responsibility consisting of the level of safety, material, financial, leadership responsibilities

c. Effort demands, which consist of physical demands and demands for constant attention

d. The demands of the situation consisting of the danger of accidents, the dangers of threats, and the comfort level of a conducive, environmentally friendly work environment. 
International Journal of Social Science (IJSS)

Vol.1 Issue.3 October 2021, pp: 241-252

ISSN: 2798-3463 (Printed) | 2798-4079 (Online)

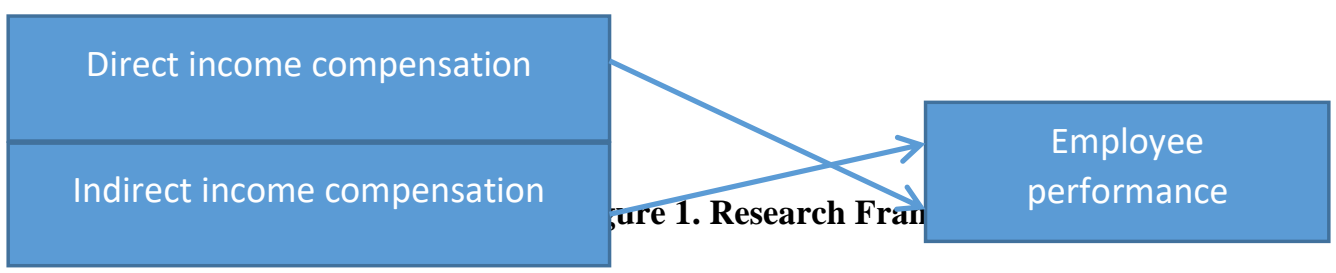

\section{RESEARCH METHOD}

The research was taken from staff level employees to division heads at insurance companies. The research approach used is the quantitative method, which is a way to conduct research by using statistical method data so as to facilitate decision makers objectively in accordance with the applicable provisions (Ghozali, 2013). The author of data collection used a questionnaire tool for data collection analysis. This questionnaire refers to the independent and dependent variables. Likert scale as a questionnaire measuring tool. Each question about each variable uses a scale with a measurement of strongly agree that is worth 5 to strongly disagree which is worth 1 (Gujarati, 2011).

The population of employees in insurance is 73 employees. According to Gujarati (2011), if the population is less than 100 respondents, it can be used as a sample. The sample used in this study found 73 respondents. The method of analysis that will be carried out is the first to test the accuracy of the data, namely validity and reliability, after that the classical assumption test includes normality test, heteroscedasticity, multicollinearity test, after reaching the next step is multiple linear regression test, determination, $\mathrm{T}$ and $\mathrm{F}$ test to see the accuracy of the data and large influence between variables.

\section{RESULTS AND ANALYSIS (10 PT)}

Table 1. Validity Test Results of Direct Income Compensation Variables

\begin{tabular}{|c|c|c|c|}
\hline & & & \\
Variabel KPL & r table & r count & Information \\
\hline KPL1 & $\mathbf{0 , 2 3 0 3}$ & $\mathbf{0 . 4 2 8}$ & Worthy \\
KPL2 & $\mathbf{0 , 2 3 0 3}$ & $\mathbf{0 . 6 7 8}$ & Worthy \\
KPL3 & $\mathbf{0 , 2 3 0 3}$ & $\mathbf{0 . 5 2 6}$ & Worthy \\
KPL4 & $\mathbf{0 , 2 3 0 3}$ & $\mathbf{0 . 4 7 9}$ & Worthy \\
KPL5 & $\mathbf{0 , 2 3 0 3}$ & $\mathbf{0 . 5 9 8}$ & Worthy \\
\hline
\end{tabular}


Validity of test results to the 73 respondents on variable compensation revenue directly with $t$ ingkat 0.05 can be concluded that 5 statement is considered feasible for me mpunyai value of $\mathrm{r}$ count $>\mathrm{r}$ table

Table 2 Validity Test Results for Indirect Income Compensation Variables

\begin{tabular}{|c|c|c|c|}
\hline & & & \\
Variabel KPT & r table & r count & Information \\
\hline KPT1 & $\mathbf{0 , 2 3 0 3}$ & $\mathbf{0 . 7 0 2}$ & Worthy \\
KPT2 & $\mathbf{0 , 2 3 0 3}$ & 0.691 & Worthy \\
KPT3 & $\mathbf{0 , 2 3 0 3}$ & $\mathbf{0 . 6 5 9}$ & Worthy \\
KPT4 & $\mathbf{0 , 2 3 0 3}$ & $\mathbf{0 . 6 6 1}$ & Worthy \\
KPT5 & $\mathbf{0 , 2 3 0 3}$ & $\mathbf{0 . 7 3 3}$ & Worthy \\
\hline
\end{tabular}

From the results of the validity test to 73 respondents on the indirect income compensation variable with a significance level of 0.05 , it can be concluded that 5 statements are considered feasible because they have an $r$ value $>$ r table

Table 3 Validity Test Results for Employee Performance Variables

\begin{tabular}{|c|c|c|c|}
\hline & & & \\
Variabel KKY & r table & r count & Information \\
\hline KNP_1 & $\mathbf{0 , 2 3 0 3}$ & .530 & Worthy \\
KNP_2 & $\mathbf{0 , 2 3 0 3}$ & .770 & Worthy \\
KNP_3 & $\mathbf{0 , 2 3 0 3}$ & .587 & Worthy \\
KNP_4 & $\mathbf{0 , 2 3 0 3}$ & .485 & Worthy \\
KNP_5 & $\mathbf{0 , 2 3 0 3}$ & .500 & Worthy \\
KNP_6 & $\mathbf{0 , 2 3 0 3}$ & .543 & Worthy \\
\hline
\end{tabular}

Sumber: Hasil Olah Data Menggunakan SPSS 25.00

From the results of the performance validity test to 73 respondents on the employee performance variable with a significance level of 0.05 , it can be concluded that 6 statements are considered feasible because they have an $r$ value $>r$ table

Tabel 4 Table 4 Reliability Test Results

\begin{tabular}{|l|c|c|}
\hline \multicolumn{2}{|c|}{ Reliability Statistics } \\
\hline Variabel & Cronbach's Alpha & N of Item \\
\hline Direct Income Compensation & 0,767 & 5 \\
\hline Indirect Income Compensation & 0,866 & 5 \\
\hline Employee Performance & $\mathbf{0 , 8 0 9}$ & $\mathbf{6}$ \\
\hline
\end{tabular}

Sumber: Hasil Olah Data Menggunakan SPSS 25.00

Based on the results of the reliability table, it is known that each variable has a reliability ( Cronbach's Alpha ) value above 0.60 , thus the measuring instrument in the study is stated to be very reliable. 
International Journal of Social Science (IJSS)

Vol.1 Issue.3 October 2021, pp: 241-252

ISSN: 2798-3463 (Printed) | 2798-4079 (Online)

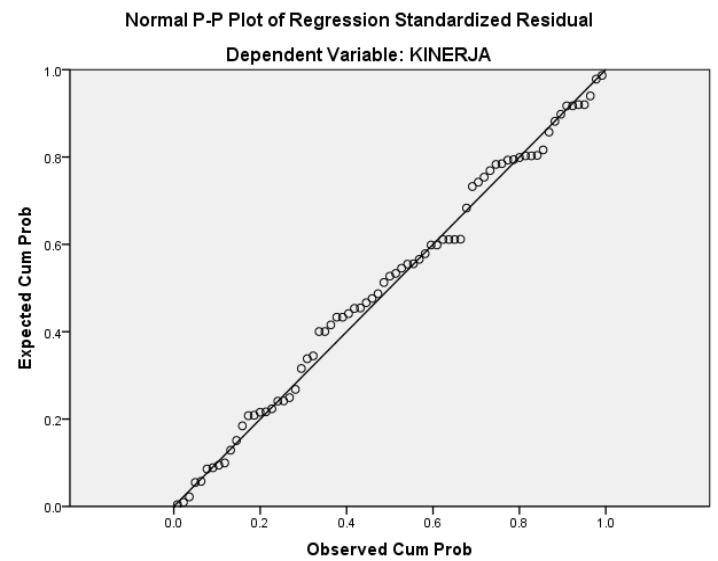

Figure 1 PP plot normality test

From the graph, it is known that the points are scattered around the diagonal line and follow the diagonal line, thus the regression model can be said to have fulfilled the normality test requirements and is normally distributed.

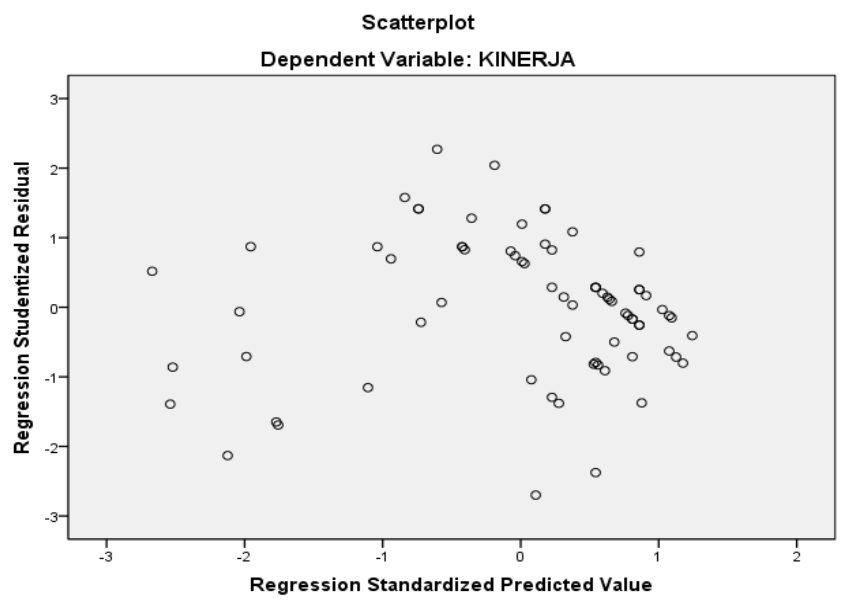

Figure 2 Heteroscedasticity Test Graphic Method

The picture above shows the results of the dots forming and scattered into an uncluttered and random pattern. This means that the pattern proves that there is no heteroscedasticity

\section{Table 5 Multicollinearity}

\begin{tabular}{|l|c|c|}
\hline \multicolumn{1}{|c|}{ Information } & Tolerance Value & VIF Value \\
\hline Direct income compensation & 0,963 & 1,038 \\
\hline Indirect Income compensation & 0,963 & 5,168 \\
\hline
\end{tabular}


The VIF value of the two regression models shows a value less than 10 (VIF $<10$ ), meaning that there is no multicollinearity. The calculation value of tolerance also proves that the value of the independent variable is less than 0.1 ( tolerance $<0.1$ ), meaning that there is no multicollinearity in the data.

Table 6 T and F test

\begin{tabular}{|l|c|c|c|c|}
\hline \multicolumn{1}{|c|}{ Variabel } & $\mathrm{T}$ & Sig. & F & Sig. \\
\hline $\begin{array}{l}\text { Kompensasi Pendapatan } \\
\text { Langsung }\end{array}$ & 13.392 & 0.000 & \multirow{2}{*}{102.921} & $.000^{\mathrm{a}}$ \\
\cline { 1 - 3 } $\begin{array}{l}\text { Kompensasi Pendapatan } \\
\text { Tidak Langsung }\end{array}$ & 2.484 & 0.015 & \\
\hline
\end{tabular}

From the analysis of the partial compensation are direct revenues (X 1 ) of the employee's performance that the $13392 \mathrm{t}$ count $>\mathrm{t}$-table is $1.6666(\mathrm{df}=\mathrm{n}-\mathrm{k}$ or $\mathrm{df}=73-2=71$ with a significance level of 0.05$)$ with a significant value of $0.000<0.05$. Thus it can be concluded that partially positive and significant effect between direct income compensation on employee performance.

While the t-count value of indirect financial compensation is $2.484>\mathrm{t}$-table, which is $1.666(\mathrm{df}=\mathrm{n}-\mathrm{k}$ or $\mathrm{df}=73-2=71$ with a significant level of 0.05 with a significant value of $0.015<0.05$. Thus, it can be concluded that partially there is a positive and significant influence between indirect income compensation on employee performance.

Simultaneously the value of F-count $102,921>\mathrm{F}$ table is 3.98 ( df $1=\mathrm{k}-1$ and $\mathrm{df} 2=\mathrm{n}-\mathrm{k}$ or df $1=2-$ $1=1$ and df $2=73-2=71$, with a significant level 0.05 with a significant value of $0.000<0.05$. Thus, it can be concluded that simultaneously there is a positive and significant effect between direct income compensation and indirect income compensation on the performance of insurance company employees.

\section{Tabel 7Analisis Koefisien Determinasi}

\begin{tabular}{|l|r|r|r|r|r|}
\hline Model & R & R Square & $\begin{array}{c}\text { Adjusted R } \\
\text { Square }\end{array}$ & $\begin{array}{c}\text { Std. Error of } \\
\text { the Estimate }\end{array}$ & $\begin{array}{c}\text { Durbin- } \\
\text { Watson }\end{array}$ \\
\hline 1 & $.864^{\mathrm{a}}$ & .746 & .739 & .31880 & 1.967 \\
\hline
\end{tabular}

a. Predictors: (Constant), Kompensasi Pendapatan Tidak Langsung, Kompensasi

Pendapatan Langsung

b. Dependent Variable: KINERJA

Sumber: Hasil Olah Data Menggunakan SPSS 25.00

The results of table 7 above are the results of the analysis of the coefficient of determination together which are explained as follows: The R value is 0.864 and the Adjusted R Square value is 0.746 . The greater the value of Adjusted R Square close to 1 (one), the independent variables are compensated income directly and compensation income does not directly affect the stronger the dependent variable is the performance of employees.

Adjusted R Square of 0739, or 74\% have me mbuktikan that the contribution percentage effect of independent variables namely compensation income directly and compensation income is not directly with the dependent variable is the performance of employees simultaneously by $74 \%$, while that of $26 \%$ can be influenced by other factors outside to these two variables.

\section{Direct Compensation}

The effect of income compensation directly affects the performance of insurance employees. It is proven by the tcount value of 13,392 with a significant level of $0.000<0.05$. A positive t-count value means that it has a very positive and significant relationship between direct income compensation and employee performance.

Direct income compensation can make insurance employees improve performance and compete to show dedication to the company. Employees who are very loyal to the company feel there is satisfaction with the provision of compensation, employees feel there is justice in providing direct income compensation. The way the company provides direct income compensation is carried out according to a predetermined time. Employee needs that are met with direct compensation income can improve employee performance 
International Journal of Social Science (IJSS)

Vol.1 Issue.3 October 2021, pp: 241-252

ISSN: 2798-3463 (Printed) | 2798-4079 (Online)

DOI: https://doi.org/10.53625/ijss.v1i3.417

The results of this study are in line with the research of Ekshu and Setiawan (2014) showing that compensation directly affects employee performance. In accordance with Damayanti and Sumaryati (2013), it shows that compensation directly affects employee performance. The amount of direct income compensation received by employees reflects the status, recognition and level of fulfillment of needs enjoyed by employees and their families

\section{Indirect Income Compensation}

Indirect income compensation has an effect on the performance of insurance employees. From the results of the analysis, the t-count value was 2.484 with a significance level of $0.015<0.05$. A positive $\mathrm{T}$-value means that it has a very positive relationship between indirect income compensation and employee performance.

The provision of indirect income compensation is more used as a complement to repay employees who have devoted their time and achievements to advance the company. The forms of indirect income compensation that can be received by employees include the addition of food allowances, giving leave, pension funds, providing health and medical insurance, a conducive work atmosphere .

Employees who are loyal to work for the company feel more protected when the employee's family gets guaranteed health benefits. Therefore, the company makes it mandatory for indirect income compensation to be given to employees who work optimally, spending time and energy on employees who have made the company achieve its goals.

The results of this study are in line with the research of Ekshu and Setiawan (2014) which shows that income compensation does not directly affect employee performance. In line with Recha (2016), partially there is a significant effect of indirect income compensation on employee performance. The existence of indirect income compensation makes employees more focused and attentive to efforts to achieve good work results, so that this fosters better performance of employees.

\section{CONCLUSION}

The results of research conducted on employees of insurance companies can be concluded, the study used 73 employees who work at PT. Insurance, analytical method using multiple linear regression test. Direct income compensation and indirect income compensation have a large influence of $74 \%$. The results showed that direct income compensation has a positive effect on employee performance with a significant level of $0.000<0.05$, meaning that employees are considered capable of improving employee performance. Furthermore, indirect income compensation has a positive effect with a cognitive level of $0.015<0.05$, meaning that the compensation provided by the company has succeeded in improving the performance of employees working well .

\section{ACKNOWLEDGEMENTS}

We would like to thank the Indonesian College of Economics, Jakarta and all of the authors' friends who have provided support, either directly or indirectly, so that the author can complete the research. Thanks to the $\mathrm{T}$ im $\mathrm{R}$ edaksi International journal of social science for their input and suggestions that have been given so that research is able to rise and useful to the reader .

\section{REFERENCES (10 PT)}

[1] Ananda Putra dkk.2016. Kompensasi Dalam Perspektif Ekonomi Islam. Jurnal Fakultas Ekonomi Islam Universitas Islam Indonesia, Vol 3(2)

[2] Andico, C., \& Hadi, S. P. 2013. Pengaruh Kompensasi dan Motivasi Kerja Terhadap Kinerja Karyawan PT. Pelabuhan Indonesia III (Persero) Terminal Peti Kemas Semarang. Jurnal Ilmu Administrasi Bisnis, Vol 2(4), 146-154.

[3] Damayanti, A. P., \& Sumaryati, S. 2013. Pengaruh Kompensasi dan Motivasi Kerja terhadap Kinerja Karyawan Perusahaan Daerah Air Minum (PDAM) Surakarta. Jupe-Jurnal Pendidikan Ekonomi, Vol 2(1).

[4] Dessler, Gary.2012. Manajeme Sumber Daya Manusia .Edisi Kesepuluh Jilid 4, PT Indeks. Jakarta.

[5] Didin Hafidhudin.2011, Manajemen Syariah dalam Praktek, Gema Insani, Jakarta, 2003

[6] Ekshu Hamdan dan Roy Setiawan.2014. Pengaruh Kompensasi Finansial dan Non Finansial Terhadap Kinerja Karyawan. Jurnal Program Manajemen Bisnis. Vol. 2(1)

[7] Ghozali, Imam.2013. Aplikasi Analisis Multivariate Dengan Program SPSS. Semarang : Badan Penerbit Universitas Diponegoro.

[8] Gitosudarmo dan Indriyo.2016. Pengantar Bisnis, edisi kedua, cetakan ketujuh, : Penerbit BPFE ,Yogyakarta

[9] Gujarati.2011. Strategi Jitu Memilih Metode Statistik Penelitian statistic penelitian dengan SPSS. Jakarta:Penerbit Andi Yogyakarta

[10] Hasibuan Malayu S.P., 2012. Manajemen Sumber Daya Manusia, Bumi Aksara, Jakarta

[11] Handoko TH.2017. Manajemen Personalia dan Sumber Daya Manusia Edisi 2, BPFE, Yogyakarta 
[12] Mangkunegara, A.A. Anwar Prabu. 2010. Manajemen Sumber Daya Manusia. PT. Remaja Rosdakarya, Bandung.

[13] Marihot, Efendi Hariandja.2012. Manajemen Sumber Daya Manusia.Jakarta: Grasindo

[14] Marihot,Efendi Hariandja.2010. Manajemen SDM, Pengadaan pengembangan pengkoordinasian dan Peningkatan produktifitas pegawai, PT. Grasindo, Jakarta.

[15] Moheriono.2014. Pengukuran kinerja berbasis kompetensi.Cetakan ketiga .Bogor : Ghalia indonesia.

[16] Mulyadi.2013. Sistem Perencanaan dan Pengendalian Manajemen (Sistem Pelipatganda Kinerja Perusahaan), Salemba Empat, Jakarta

[17] Rachmawati, Ike Kusdyah. 2007. Manajemen Sumber Daya Manusia. CV. Andi Offset. Yogyakarta.

[18] Recha Putrie Etichasarie, dkk. 2016. Pengaruh Kompensasi Non Finansial Terhadap Kepuasan Kerja dan Intention To Leave. Jurnal Administrasi Bisnis. Vol. 40(7)

[19] Rivai, Veithzal. 2008. Manajemen Sumber Daya Manusia Untuk Perusahaan Dari Teori Ke Praktik. PT. Raja Grafindo Persada, Jakarta.

[20] Simamora dan Henry.2016. Manajemen Sumber Daya Manusia, PT Gramedia Pustaka Utama, Jakarta,

[21] Wilson Bangun.2012.Manajemen Sumber Daya Manusia, Erlangga, Jakarta 